\title{
PENERAPAN MICROMOTION STUDY DALAM ANALISIS PRODUKTIVITAS DESAIN PERALATAN KERJA CETAK SARING
}

\author{
Yanuar Herlambang ${ }^{1}$, Andar Bagus Sriwarno, Muh. Ihsan DRSAS \\ ${ }^{1}$ Magister Desain FSRD Institut Teknologi Bandung, Indonesia \\ e-mail: herlambangyanuar@yahoo.com
}

\begin{abstract}
Abstrak: Industri cetak saring termasuk kedalam kategori Industri Kecil Menengah (IKM) yang menggunakan teknologi cetak sederhana, industri ini memiliki banyak keterbatasan yang berimbas kepada rendahnya produktivitas. Dalam proses pencetakan multi-warna terdapat ketergantungan yang tinggi terhadap kemampuan operator terutama saat proses set-up dan cetak sehingga pekerjaan menjadi tidak efektif dan tidak efisien, sehingga.

Metode analisis yang digunakan dalam penelitian ini adalah Motion Study dengan teknik pengumpulan data Micromotion Study yang berbasis video guna menghasilkan tingkat produktivitas dari desain peralatan kerja lama sebagai pertimbangan dalam pengembangan desain usulan yang baru. Ruang lingkup penelitian adalah tingkat produktivitas dari segi efisiensi ruang, proses set-up, proses cetak, dan simulasi produksi multi-warna.

Berdasarkan hasil analisis dapat disimpulkan bahwa desain Meja Panjang memiliki keunggulan pada kesederhanaan dan visibilitas sistem kerja seperti pada proses penggantian multi-skrin dan proses trouble shooting, akan tetapi memiliki kekurangan seperti rendahnya efisiensi penggunaan ruang, efisiensi jarak transportasi, dan efisiensi waktu set-up, sehingga dapat menghambat proses naik cetak warna berikutnya bahkan proses produksi secara keseluruhan.
\end{abstract}

Kata kunci: cetak multi-warna, ikm, micromotion, motion study, produktivitas, set-up

\section{Pendahuluan}

Teknik cetak saring di Indonesia pada perkembangannya sudah banyak digunakan oleh masyarakat luas (Bandi, 2004) termasuk berbagai industri kreatif seperti industri fesyen, penerbitan dan percetakan, periklanan, kriya, dan desain. Adapun jenis produk yang dapat menerapkan reproduksi gambar atau tulisan menggunakan teknik cetak saring adalah sangat beragam, beberapa diantaranya seperti di industri fesyen terdapat produk: kaos; topi; tas kasual, di industri penerbitan dan percetakan terdapat produk: cover buku; kartu undangan; stiker, di industri periklanan terdapat produk: poster; spanduk, di industri kriya terdapat produk: keramik; gelas; kayu, di industri desain terdapat produk: kemasan produk; interior; grafis produk, dan beberapa produk lainnya. 
Sebagai teknik cetak yang sederhana dan murah teknik cetak saring ini cocok digunakan oleh kalangan industri kecil menengah (IKM) yang pada umumnya memiliki banyak keterbatasan. Beberapa keterbatasan atau kendala umum IKM yang diidentifikasi oleh Badan Pusat Statistik (2003) diantaranya seperti penguasaan teknik produksi atau teknologi yang konvensional/sederhana, rendahnya kemampuan finansial/permodalan, rendahnya penerapan manajemen yang baik, keterbatasan sumber daya manusia sehingga kemampuan IKM dalam meningkatkan kapasitas produksi juga masih rendah. Produk maupun teknik sederhana yang dimiliki IKM rentan untuk diikuti atau ditiru sehingga persaingan antar IKM pun lebih ketat, oleh sebab itu salah satu penekanan yang harus diperhatikan untuk dapat bersaing adalah mengenai inovasi agar tetap mampu bertahan dan berkembang. Banyak kita temui industri kecil muncul karena kebetulan berada pada tempat yang sesuai dan momentum yang tepat, akan mereka tetapi tidak menyadari apa yang membuat industri itu eksis dan dapat bertahan sehingga ketika banyak pemain baru masuk dan persaingan menjadi lebih berat, mereka tidak ada persiapan diri dan tidak memiliki stategi untuk mengembangkan, yang pada akhirnya mengalami kesulitan dalam bertahan bahkan mengancam keberlangsungan industri yang mereka bangun.

Diharapkan tersedia formula yang tepat dan sesuai untuk IKM agar dapat mengukur produktivitas, sehingga pengembangan desain selanjutnya dapat lebih tepat sasaran, penekanan yang diharapkan adalah mengurangi ketergantungan kemampuan operator cetak saring untuk mendapatkan hasil terbaik dalam waktu yang cepat - terutama dalam proses set-up/persiapan skrin hingga proses cetak sehingga nantinya desain baru memiliki tingkat human errors yang rendah dan dapat dikuasai dengan mudah, cepat dan baik oleh operator-operator cetak saring lain meskipun mereka belum memiliki jam terbang yang tinggi atau pengalaman yang banyak, karena didalam proses produksi cetak saring jika terdapat kesalahan yang menyebabkan reject maka waktu yang dibutuhkan untuk memperbaiki atau mengganti kerusakan dalam jumlah sedikit akan sama atau bahkan seringkali lebih lama jika dibandingkan dengan proses produksi cetak saring baru untuk pengerjaan dalam jumlah banyak sekaligus.

\section{Landasan teori}

\subsection{Motion study}

Motion Study atau studi gerakan adalah sebuah studi yang sistematis mengenai sistem kerja dengan tujuan mencari metode yang lebih baik untuk sebuah pekerjaan, studi ini dipelopori oleh Frank B. Gilbreth dan istrinya Lillian M. Gilbreth (Barnes, 1980), studi gerakan digunakan untuk menganalisis beberapa gerakan bagian badan pekerja/operator dalam menyelesaikan pekerjaannya sehingga diharapkan gerakan-gerakan yang tidak efektif dapat dikurangi atau bahkan dihilangkan, gerakan-gerakan yang efektif akan berpengaruh terhadap penghematan waktu kerja dan juga penghematan pemakaian fasilitas-fasilitas yang digunakan dalam pekerjaannya (Madyana, 1996). 
Tujuan dari motion study adalah merangkai gerakan-gerakan yang efektif dan ekonomis sehingga pekerjaan yang dilakukan oleh operator menjadi lebih mudah dan laju produksi dapat ditingkatkan (Wignjosoebroto, 2003), kondisi tersebut diperoleh dengan cara memperbaiki terlebih dahulu kondisi pekerjaan dengan penerapan prinsip-prinsip ekonomi gerakan.

\subsection{Micromotion study}

Micromotion study adalah bagian dari studi gerakan yang dikembangkan oleh Frank B. Gilbreth yang merupakan sebuah teknik pengumpulan data gerakan operator menggunakan kamera motion picture film atau video (Pigage \& Tucker, 1954), menurut Barnes (1980) micromotion study merupakan studi tentang elemen fundamental atau bagian-bagian dari sebuah operasi yang dilakukan dengan menggunakan kamera motion picture yang dilengkapi dengan alat pengukuran waktu yang secara akurat mengindikasikan interval waktu dalam film motion picture.

Dalam studi gerakan terdapat beberapa teknik pengumpulan data atau teknik pengamatan, micromotion study termasuk dalam salah satu klasifikasi selain visual motion study, perbedaan kedua studi ini adalah dalam proses pengamatannya, visual motion study pengamatan yang dilakukan adalah dengan cara melihat secara langsung terhadap sebuah operasi kemudian dicatat kedalam peta proses operator, sedangkan micromotion study dalam pengamatannya menggunakan bantuan peralatan khusus (movie camera) untuk merekam gerakangerakan kerja yang biasanya berlangsung cepat dan berulang-ulang (Wignjosoebroto, 2003).

Barnes (1980) menerangkan bahwa Micromotion study menyediakan teknik yang unik untuk membuat analisis sebuah pekerjaan, teknik tersebut dapat mendokumentasikan secara permanen data berbasis rekaman video dan memiliki pencatatan waktu dari sebuah aktivitas sehingga dapat dilihat dan dianalisis ulang kapan pun saat dibutuhkan, teknik micromotion study biasanya diasosiasikan dengan penggunaan kamera video dengan kecepatan antara 960-1000 frame per menit atau $16 \mathrm{fps}$ bahkan dapat lebih besar tergantung kebutuhan, misalkan untuk merekam gerakan yang sangat cepat atau terdapat gerakan-gerakan yang sangat kompleks, prosedur micromotion study adalah sebagai berikut:

1. Mendokumentasikan pekerjaan atau operasi yang akan dipelajari menggunakan kamera video.

2. Menganalisis pekerjaan yang telah direkam.

3. Memetakan hasil dari analisis.

4. Mengembangkan perbaikan metode menggunakan proses problem-solving.

\subsection{Produktivitas}

Produktivitas adalah hubungan antara masukan (input) dan keluaran (output) suatu sistem produksi, jika dalam proses produksi menghasilkan lebih banyak output dengan input yang sama maka disebut memiliki peningkatan produktivitas, begitu juga walaupun hanya menghasilkan output yang sama akan tetapi input yang 
dibutuhkan lebih rendah dapat juga dikatakan sebagai peningkatan produktivitas (Arman, 2006).

Konsep rasio output dibagi input bisa dipakai di dalam menghitung produktivitas kerja di semua sektor kegiatan, pengukuran produktivitas dapat dilakukan dengan menghitung produktivitas total, yaitu perbandingan antara total keluaran dengan total masukan per satuan waktu, semua faktor masukan terhadap total keluaran diperhitungkan. Arimbawa (2010) memformulasikan produktivitas sebagai berikut:

$$
\text { Produktivitas }=\frac{\text { Luaran (output) }}{\text { Masukan (input) } \mathrm{x} \text { Waktu (time) }}
$$

Dalam produktivitas kerja, secara garis besarnya terdapat dua faktor utama yaitu: (1) faktor teknis: yaitu faktor yang berhubungan dengan pemakaian dan penerapan peralatan atau teknologi dan lingkungan kerja dan (2) faktor manusia: faktor yang berpengaruh terhadap usaha yang dilakukan manusia di dalam menyelesaikan pekerjaan yang menjadi tugas dan tanggung jawabnya.

Peningkatan produktivitas menurut Wignjosoebroto (2003) tidak boleh menurunkan kualitas hasil kerja atau produk yang dihasilkan, oleh sebab itu pengendalian kualitas (quality control) harus tetap dijalankan, adakalanya peningkatan kecepatan produksi berimbas pada tingginya tingkat kesalahan atau cacat dari keluaran yang dihasilkan. Reduksi potensi kesalahan dapat dilakukan dengan melakukan analisis metode kerja yang lebih baik, pelatihan operator, penggunaan peralatan kerja yang lebih presisi, penetapan standar kecepatan yang optimal dan sebagainya.

\section{Metodologi}

Pendekatan dalam penelitian ini adalah eksperimental dengan luaran data kuantitatif dengan tujuan explanatory yaitu produktivitas desain lama peralatan kerja cetak saring konvensional atau desain existing dengan jenis Meja Panjang, berbagai data yang dibutuhkan didapatkan dengan teknik pengamatan micromotion study yang dikombinasikan dengan pendekatan simulasi, data yang didapat diolah atau dianalisis menjadi matriks sehingga menghasilkan data mengenai kekurangan/masalah yang terdapat dalam desain existing dan akan menjadi acuan atau kriteria dalam pengembangan produk baru/redesain.

Langkah awal untuk mengidentifikasi desain lama adalah dengan menggunakan tahap observasi dan interview kemudian dilengkapi dengan proses perekaman proses kerja menggunakan kamera video, metode analisis yang digunakan adalah pendekatan motion study dengan tipe kuasi eksperimen atau control group. Teknik pengumpulan data yang digunakan adalah micromotion study, teknik ini bertujuan merekam segala kegiatan dalam proses produksi cetak saring multiwarna menggunakan kamera video dengan berbagai angle yang kemudian dapat diputar ulang dengan teknik real time, slow-motion ataupun time-lapse. Pengamatan ulang dan penulisan laporan ditampilkan dengan teknik fragmentasi 
video ke bentuk tabel gambar dengan standar frame $1 \mathrm{fps}$ dan $0,25 \mathrm{fps}$, data yang dikumpulkan termasuk data identifikasi dari desain lama atau existing. Proses analisis menggunakan beberapa peta kerja, dengan peta ini semua kegiatan produksi sejak pra-cetak hingga proses cetak diurai.

\subsection{Variabel eksperimen}

Variabel yang digunakan adalah desain peralatan kerja lama, banyaknya jumlah aktivitas/proses kerja, jumlah waktu yang diperlukan dalam proses produksi, jarak transportasi, dan tingkat akurasi.

1. Variabel penyebab (independent) adalah peralatan kerja lama (Meja Panjang).

2. Variabel akibat (dependent) berupa kontinum ratio untuk mengungkapkan efisiensi waktu proses produksi, banyaknya jumlah aktivitas kerja.

3. Variabel kontrol adalah faktor karakteristik IKM yaitu keterbatasan luas stasiun kerja, keterbatasan teknologi, dan keterampilan SDM yang rendah.

\subsection{Pengumpulan Data}

1. Metode pengumpulan data untuk pengukuran produktivitas menggunakan teknik micromotion study, pengumpulan data dilakukan dengan menggunakan kamera video, pengambilan gambar bertujuan untuk dapat merekam seluruh aktivitas tertentu yang akan diukur, informasi yang diperoleh dari metode ini adalah:

a. Rangkaian aktivitas kerja (operasi, transportasi, inspeksi, penundaan, dan penyimpanan).

b. Banyaknya proses kerja (satuan angka).

c. Jarak yang ditempuh operator (satuan centimeter). Data mengenai jarak dibagi menjadi 2 yaitu jarak dalam melakukan proses set-up dan jarak dalam melakukan proses cetak. Proses set-up sendiri terbagi lagi menjadi dua data yaitu pemasangan guide system dan kalibrasi skrin - bahan.

d. Waktu yang dibutuhkan untuk mengerjakan masing-masing kegiatan tersebut sampai pekerjaan selesai secara menyeluruh (satuan detik). Data mengenai waktu dibagi menjadi 2 yaitu waktu dalam melakukan proses set-up dan waktu dalam melakukan proses cetak.

e. Banyaknya kapasitas bahan yang akan dicetak (satuan angka). Data mengenai kapasitas dibagi menjadi 2 yaitu kapasitas dalam tiap siklus cetak, dan kapasitas keseluruhan dari pencetakan pertama hinga pencetakan terakhir.

f. Data mengenai proses set-up dan proses cetak didapat dari dua cara pengumpulan, eksperimen parsial per-proses dan simulasi produk keseluruhan proses.

2. Metode dokumentasi untuk analisis produktivitas menggunakan tabel gambar fragmentasi proses kerja, tabel peta proses kerja, dan peta diagram aliran.

\subsection{Instrumen Penelitian}

Peralatan-peralatan yang digunakan dalam pengumpulan data dan pengamatan adalah sebagai berikut: 
1. Form peta kerja untuk micromotion Study, yang terdiri dari peta proses produksi, dan peta diagram aliran produksi.

2. Gambar urutan aktivitas kerja berupa fragmentasi dengan standar frame per-seconds (fps) dari file video ke bentuk gambar berurutan.

3. Aplikasi pemutar video merek GOM player digunakan untuk memutar file video hasil rekaman proses produksi, dapat memutar dengan kecepatan normal, slow motion dan faster.

4. Perangkat lunak pengeditan video merek Adobe serial After Effects CS6, digunakan untuk mengedit video hasil observasi, dan proses produksi.

5. Kamera video digital merek JVC model GR-D33AG buatan Jepang, digunakan untuk mengambil video aktivitas kerja operator di beberapa sudut pandang.

6. Kamera digital merek Sanyo model VPC-T700T 7.0 mega pixels buatan China, untuk mengambil video aktivitas kerja operator dari sudut pandang samping.

7. Smartphone Samsung model S4 buatan china, digunakan sebagai sound recorder dan alat pengumpulan data basis gambar dan video, seperti gambar saat observasi dan video aktivitas kerja operator dari sudut pandang atas.

8. Dudukan kamera tipe tripod merek AtoB model AHoldB buatan China, digunakan sebagai dudukan kamera digital yang diletakkan di atas meja di samping operator.

9. Dudukan kamera tipe kaki tunggal merek Monopod buatan china, digunakan sebagai dudukan kamera smartphone yang dilekatkan diatas langit-langit.

10. Printer merek Canon seri PIXMA iP1980, digunakan untuk mencetak hasil gambar fragmentasi dari data.

11. Lampu neon panjang (2 set) merek Philips buatan Indonesia, digunakan sebagai lighting tambahan yang disusun diatas meja operator.

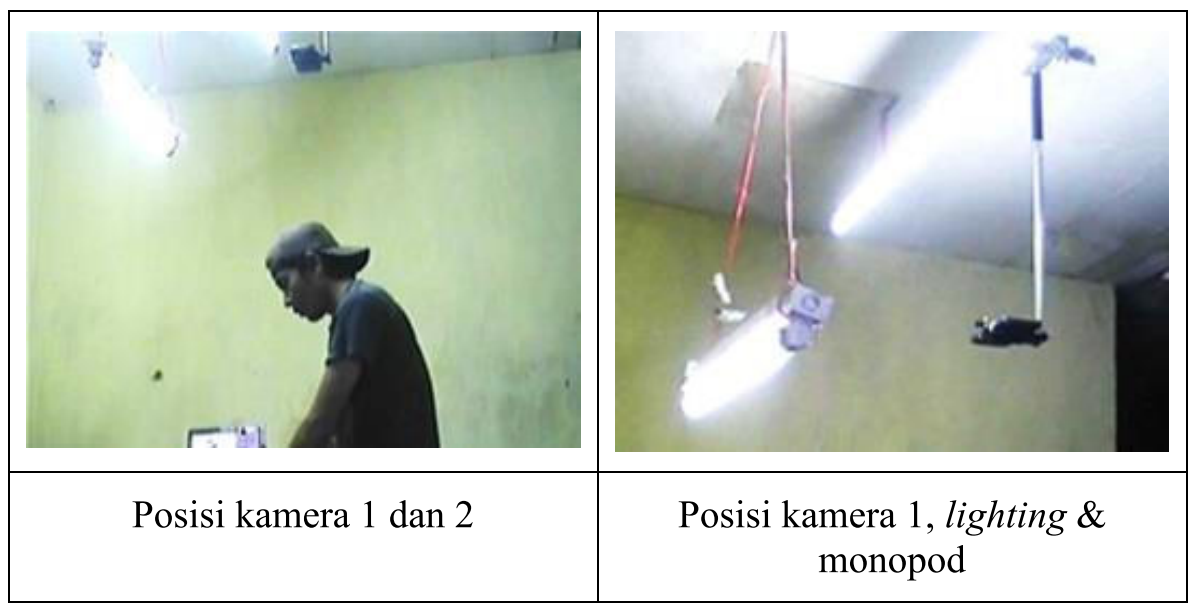




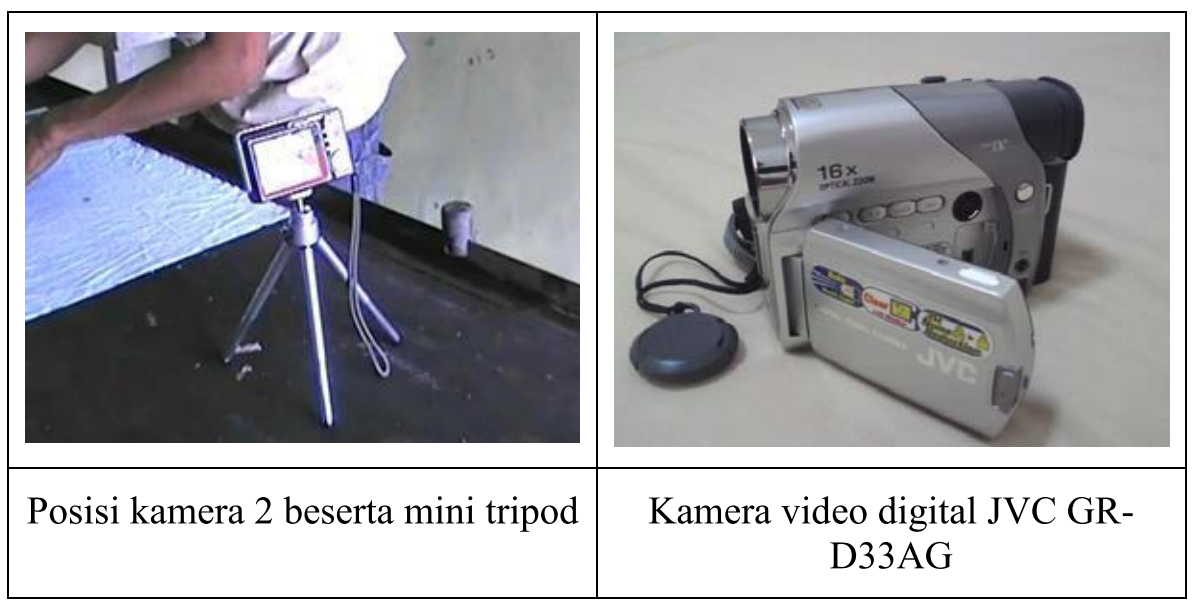

Gambar 3.3.1 Peralatan pendukung Micromotion Study.

\subsection{Prosedur Penelitian}

1. Tahap persiapan

a. Persiapan form peta kerja, yang terdiri dari peta proses dan peta diagram aliran.

b. Persiapan peralatan rekam, peralatan yang digunakan didata mengenai kemampuan daya rekam seperti tingkatan ketajaman gambar, standar fps, proses transfer data yang dibutuhkan, dan sebagainya.

c. Persiapan posisi kamera beserta teknik pengaturan ketinggian \& dudukannya (kamera 1, 2, \& 3), posisi operator, dan pencahayaan tambahan.

d. Persiapan 3 desain peralatan kerja cetak saring, berikut bahan cetak dan cat warna cetak saring.

e. Persiapan protokoler penelitian. Protokoler ini mengatur urutan kegiatan produksi menggunakan desain meja cetak saring lama atau existing mulai dari proses persiapan peralatan kerja cetak saring hingga proses cetak dilakukan. Protokoler penelitian tersebut dapat diuraikan sebagai berikut:

1) Persiapan peralatan kerja cetak saring.

2) Pengumpulan data berbasis video dari desain peralatan kerja dari tahap awal hingga akhir. Aktivitas yang direkam adalah menggunakan peralatan kerja meja cetak saring pada tahap pemasangan guide system dan skrin, proses kalibrasi tanda registrasi skrin-bahan cetak, proses cetak ke atas bahan, dan proses mengganti skrin pertama dengan skrin untuk warna selanjutnya.

3) Analisis rekaman video.

4) Matriks produktivitas desain existing. 


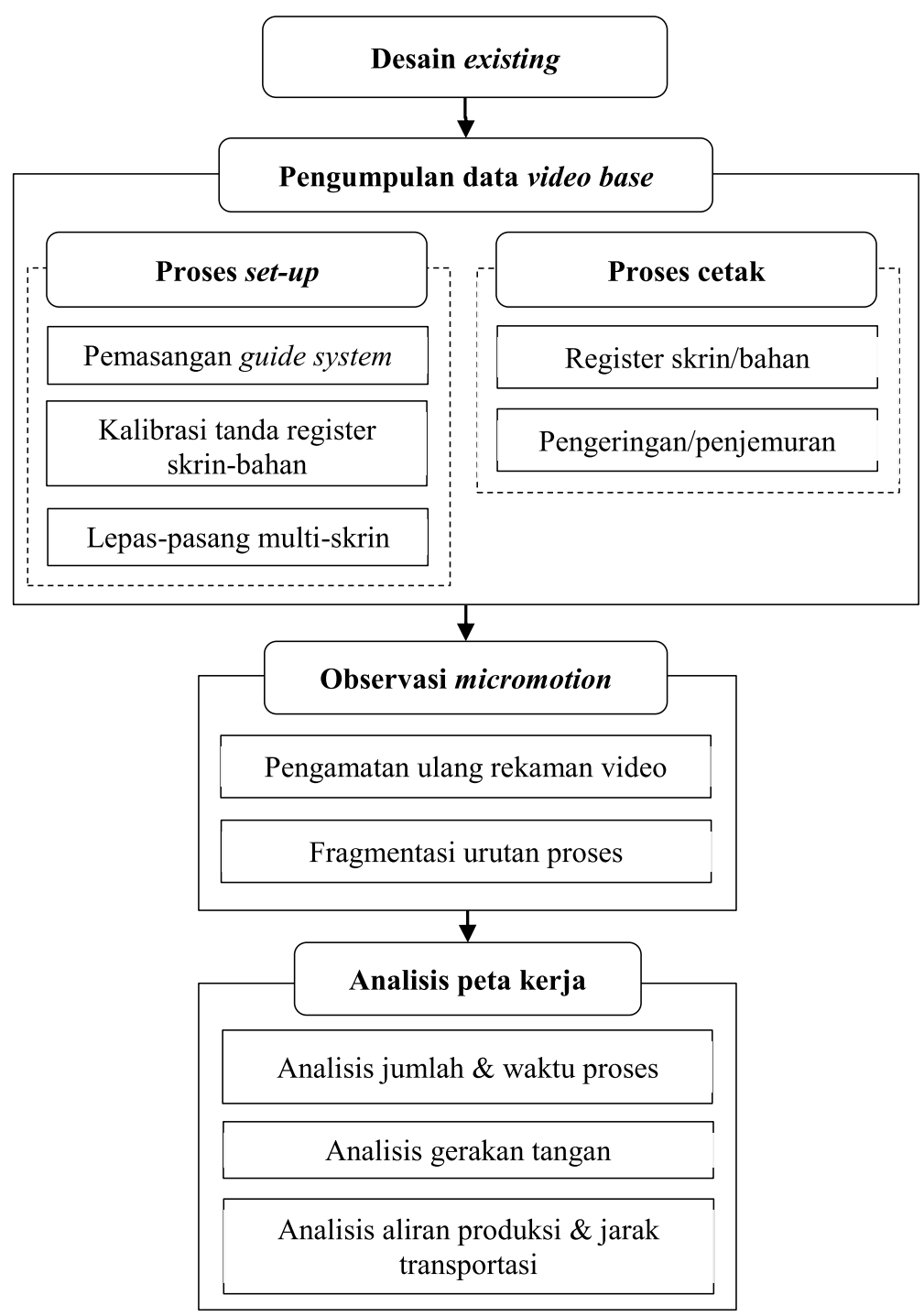

Gambar 3.4.1 Prosedur analisis desain peralatan kerja existing.

2. Tahap pelaksanaan

a. Persiapan peralatan kerja cetak saring existing yaitu meja panjang beserta bahan \& cat yang dibutuhkan dan pengaturan posisi alat perekam video \& pencahayaan.

b. Pengumpulan data berbasis video dari tahap awal hingga akhir. Perekaman tahap pertama adalah merekam aktivitas menggunakan peralatan kerja meja cetak saring pada tahap pemasangan guide system dan skrin.

c. Perekaman tahap kedua adalah aktivitas dalam proses kalibrasi tanda registrasi skrin dengan tanda registrasi bahan cetak.

d. Perekaman tahap ketiga adalah aktivitas dalam proses cetak ke atas bahan. 
e. Perekaman tahap keempat adalah aktivitas dalam proses mengganti skrin pertama dengan skrin untuk warna selanjutnya.

f. Pengeditan data rekaman diikuti analisis menggunakan proses putar ulang video, fragmentasi video urutan aktivitas produksi, dan peta kerja.

g. Hasil analisis disusun dalam tabel proses kerja, tabel aliran kerja, dan tabel simulasi produksi.

\section{Hasil dan Pembahasan}

Desain meja panjang yang umum digunakan adalah menggunakan sistem rel adjustable dengan stopper $\mathrm{T}$ bar yang dapat diatur posisinya, sistem ini menggunakan plat besi siku sebagai rel atau acuan sumbu $x$ pada meja cetak, sistem adjustable menghadap ke atas. Modul sebuah meja panjang memiliki ukuran $122 \mathrm{~cm}$ x $244 \mathrm{~cm}$ x $90 \mathrm{~cm}$ menggunakan multiplex dengan ketebalan $1,5 \mathrm{~cm}$ atau $2 \mathrm{~cm}$ yang dilapisi kain tebal.

Desain meja cetak saring dengan sistem meja panjang pada dasarnya menggunakan alas dari papan lebar kemudian dihamparkan diatas kaki-kaki dan memiliki sistem regitrasi nok dibagian sisinya sebagai stopper untuk skrin. Papan yang digunakan biasanya adalah papan multiplek atau multiblok dengan ketebalan minimal $10 \mathrm{~mm}$ yang dilapisi dengan lembaran bahan spons atau kanvas sebagai bantalan, untuk ruang yang luas papan multiplek digabungkan menjadi beberapa lembar sehingga lebih panjang.

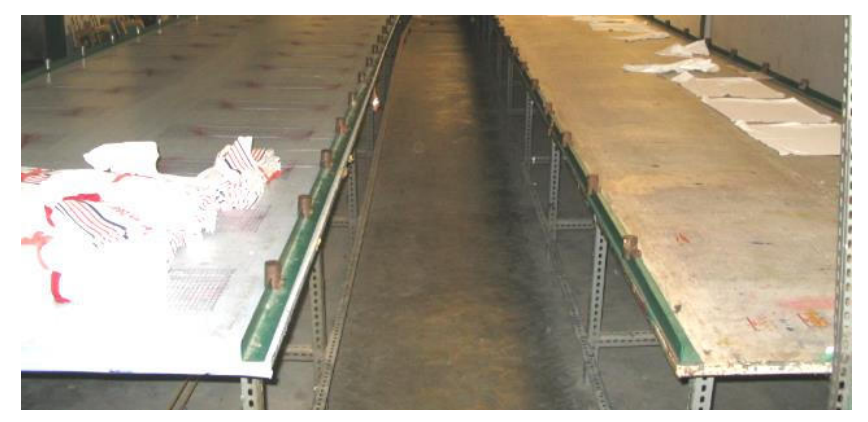

Gambar 4.1 Stasiun kerja desain meja panjang modular dengan adjustable guide system dan stopper (nok) yang digunakan oleh Baladewa Holis. (Sumber: penelitian)

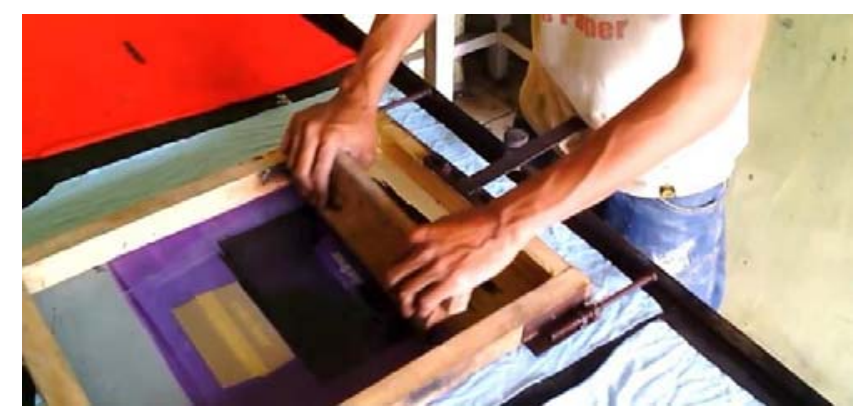

Gambar 4.2 Proses cetak desain meja panjang dengan sistem adjustable stopper $T$ bar (plat besi dan mur-baut) pada skrin. (Sumber: penelitian) 
Proses produksi menggunakan desain meja panjang secara umum terdiri dari sepuluh tahap yaitu: pemasangan bahan; pemasangan guide system; pengaturan posisi bahan; kalibrasi posisi; persiapan naik cetak; transportasi ke bahan cetak; registrasi skrin terhadap bahan; pencetakan cat ke bahan; inspeksi terhadap hasil cetak; dan pengeringan bahan yang telah dicetak.

\subsection{Proses kerja desain meja panjang}

Dalam analisis proses kerja desain meja panjang dalam penelitian ini mengacu pada penggunaan jenis 3 point adjustable guide system, yaitu penggunaan dua baut untuk pengaturan posisi sumbu $y$, dan stopper T-bar untuk pengaturan posisi sumbu $x$.

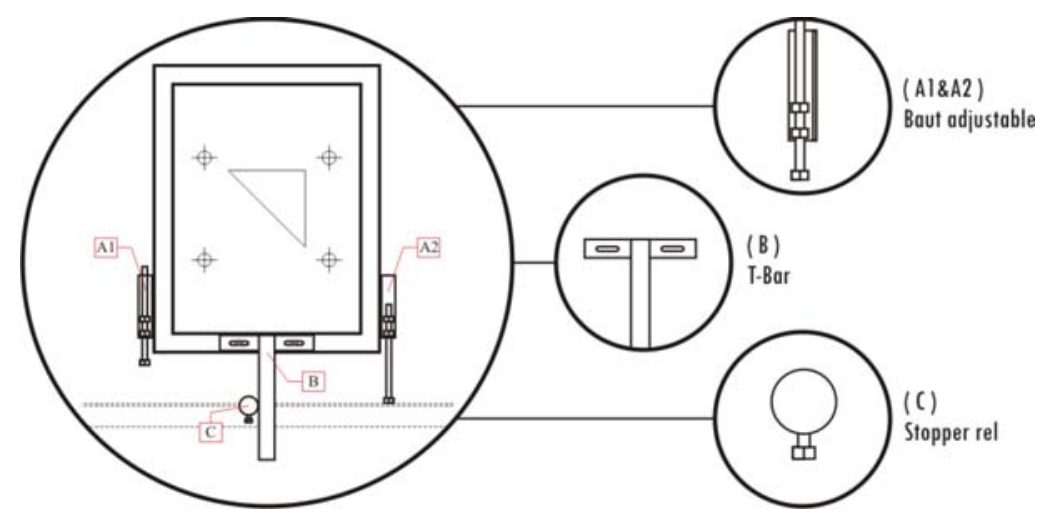

Gambar 4.3 Guide system part desain meja panjang.

Dalam proses pemasangan guide system operator harus merakit 4 unit, yaitu 2 unit baut adjustable (kanan dan kiri), 1 unit T-bar, dan 1 unit adjustable stopper. Penguat dudukan baut adjustable masing-masing memiliki 2 sekrup, begitu pula dengan pengikat $T$-bar, sedangkan untuk adjustable stopper hanya memiliki satu baut pengencang. Proses yang memakan waktu lama adalah pemasangan unit dudukan baut adjustable (kanan dan kiri) dan unit T-bar.

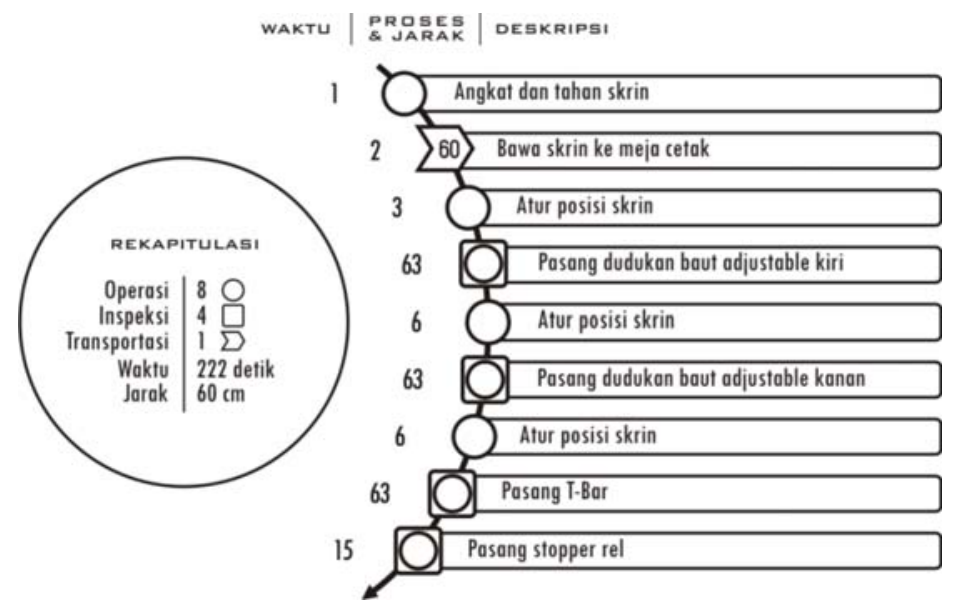


Gambar 4.4 Proses pemasangan guide system skrin multi-warna desain meja panjang.

Dalam proses pemasangan guide system skrin multi-warna terdapat delapan operasi atau kegiatan yang dibutuhkan, mulai dari mengangkat skrin hingga memasang stopper rel. Tahapan yang memakan waktu terlama adalah tahap pemasangan dudukan baut kanan-kiri dan pemasangan $T$-bar yang masing-masing memerlukan waktu proses 63 detik dikarenakan memiliki part baut adjustable yang harus diatur secara manual dan harus dilakukan cek ulang atau inspeksi.

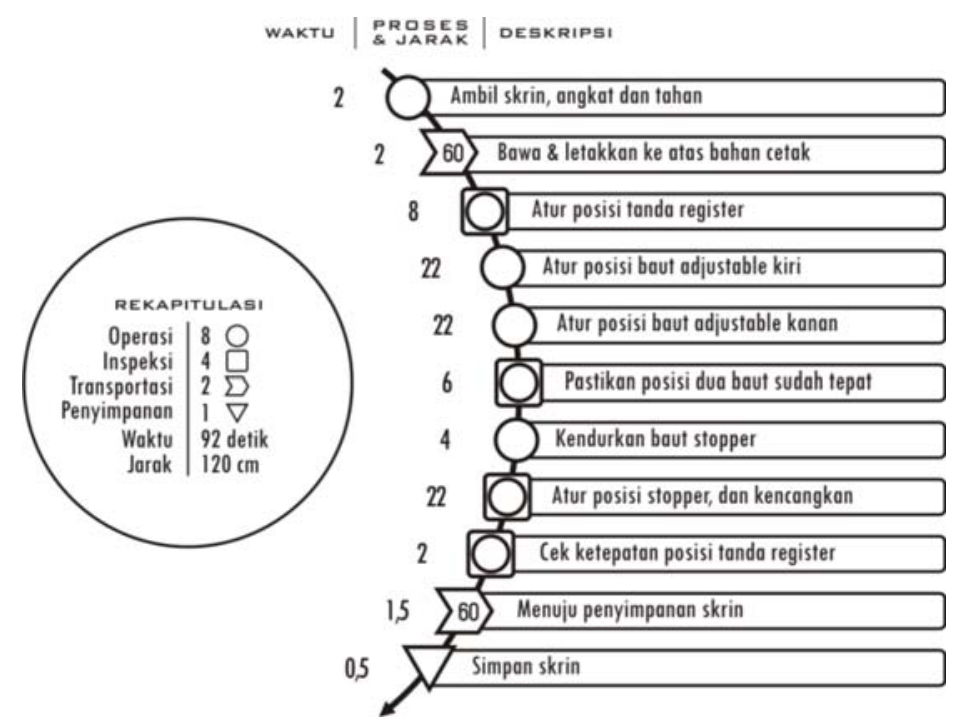

Gambar 4.5 Proses kalibrasi posisi tanda register desain meja panjang.

Proses kalibrasi skrin pada desain meja panjang adalah proses mengatur posisi skrin agar secara tepat memiliki posisi yang sama dengan acuan gambar yang ada pada bahan. Untuk mempermudah dan lebih presisi maka digunakan tanda registrasi pada film positif yang digunakan juga pada saat peng-afdrukan skrin.

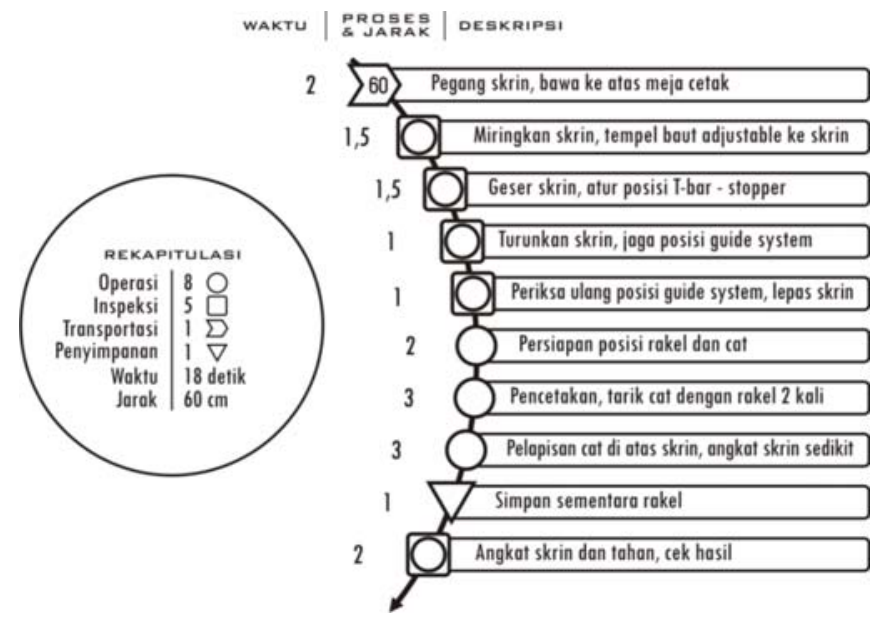

Gambar 4.6 Proses cetak warna menggunakan desain meja panjang. 


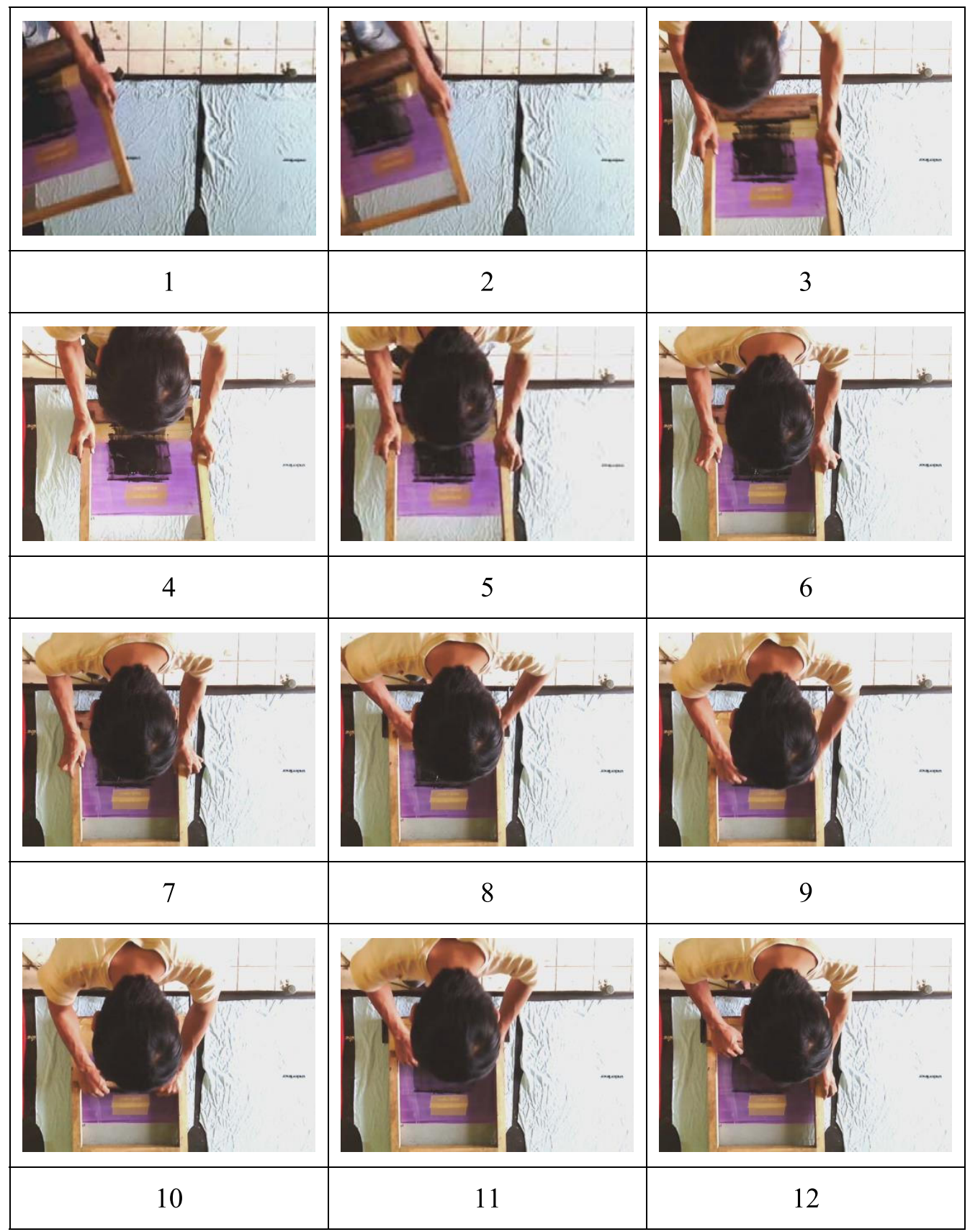




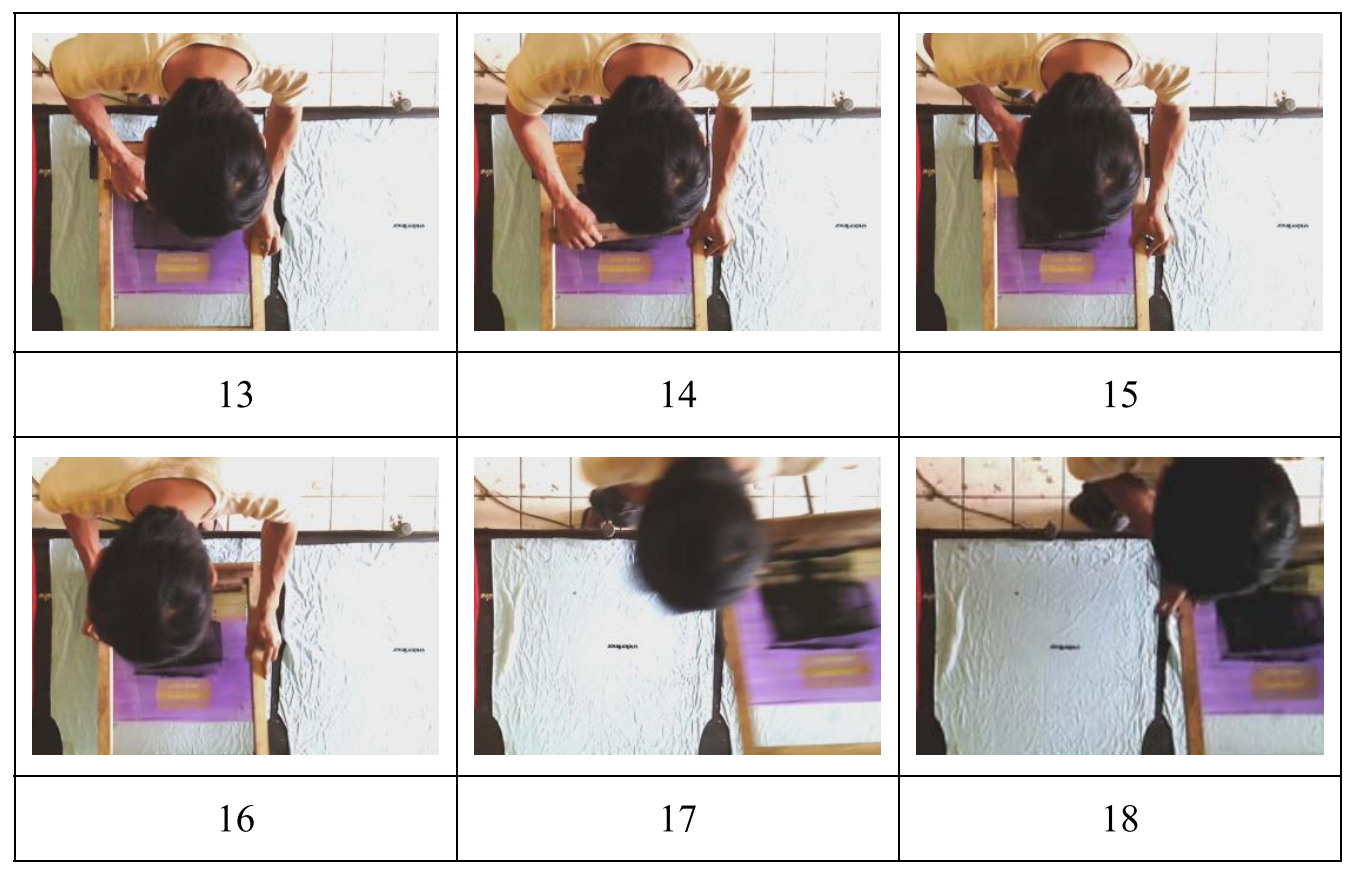

Gambar 4.7 Fragmentasi video 1 frame per-detik, urutan gerakan dalam proses cetak satu siklus produksi menggunakan desain meja panjang, 2 kali tarikan rakel.

Dalam proses cetak menggunakan desain meja panjang dihitung sejak proses transportasi dari meja persiapan menuju meja cetak, diikuti oleh proses registrasi posisi skrin, pencetakan warna, dan pemeriksaan hasil cetak. Proses persiapan rakel dan cat adalah pengaturan (pre-positioning) posisi rakel di bagian atas gambar atau cat, sehingga siap untuk dilakukan proses berikutnya yaitu mendorong cat dengan rakel agar cat dapat melalui pori skrin menuju bahan cetak di bagian bawah skrin.

Pelapisan cat di atas skrin setelah proses cetak adalah agar pori skrin tidak, pelapisan tersebut tidak seperti proses cetak akan tetapi hanya melapisi bagian atas skrin dengan tanpa memberikan tekanan terhadap cat sehingga cat tidak akan tembus melalui skrin. 


\subsection{Aliran kerja meja panjang}

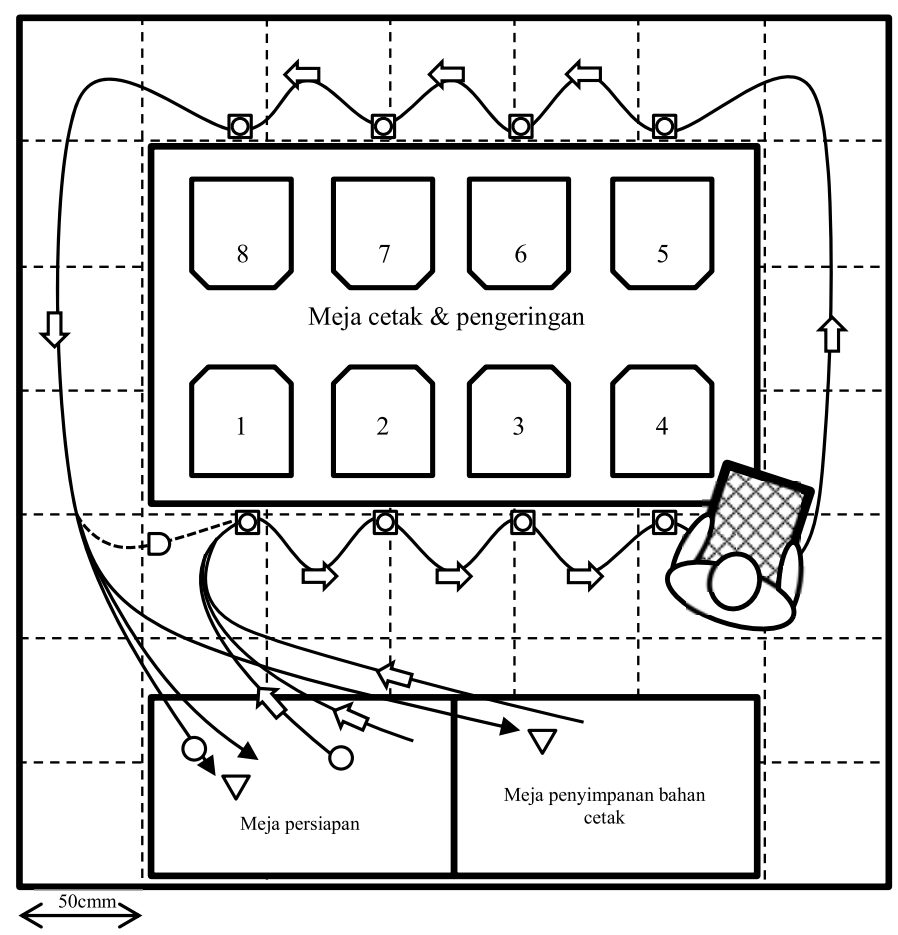

Gambar 4.8 Layout stasiun kerja meja panjang, luas ruang 3,5m x 3,5m, skala $1: 30$.

Dalam peta diagram aliran dapat diketahui bagimana lintasan yang digunakan dalam proses produksi menggunakan meja panjang, desain meja panjang mengharuskan operator berjalan untuk menghampiri bahan satu ke bahan berikutnya dan berputar kembali untuk melakukan proses berikutnya.

\subsection{Simulasi produksi meja panjang}

Dengan memiliki data mengenai proses-proses utama dalam proses produksi dan data-data hasil observasi pada saat proses produksi berlangsung maka kita dapat membuat sebuah simulasi untuk melihat bagaimana tingkat produktivitas pada saat proses produksinya. Semua proses produksi sejak persiapan hingga proses cetak disusun di dalam sebuah peta proses kerja yang dibagi menjadi 2 kolom yaitu kolom set-up dan kolom cetak.

Tabel 4.9 Rekapitulasi simulasi produksi 32 bahan menggunakan desain meja panjang, termasuk proses persiapan.

\begin{tabular}{|l|l|l|}
\hline \multicolumn{2}{|l|}{ Deskripsi } & Jumlah \\
\hline Proses & & \\
\hline Operasi & 0 & $\mathbf{5 0 0}$ \\
\hline Inspeksi & $\square$ & $\mathbf{2 6 0}$ \\
\hline Transportasi & $\Rightarrow$ & $\mathbf{1 6 8}$ \\
\hline Penundaan & $D$ & $\mathbf{1 2 8}$ \\
\hline
\end{tabular}




\begin{tabular}{|c|c|}
\hline Penyimpanan & 20 \\
\hline Tot. proses & 1.076 proses \\
\hline \multicolumn{2}{|l|}{ Waktu } \\
\hline Waktu proses set-up & 13.572 \\
\hline Waktu proses cetak & 5.868 \\
\hline Tot. waktu (detik) & $\begin{array}{l}19.440 \text { detik }=5 \text { jam } 24 \text { meni } \\
\text { Odetik }\end{array}$ \\
\hline \multicolumn{2}{|r|}{ ( } \\
\hline Jarak proses set-up & 16.040 \\
\hline Jarak proses cetak & 61.600 \\
\hline Tot. jarak $(\mathrm{cm})$ & $77.640 \mathrm{~cm}=776,4$ meter \\
\hline \multicolumn{2}{|l|}{ Siklus } \\
\hline Siklus cetak & 4 siklus \\
\hline Jumlah bahan tiap siklus & 8 bahan \\
\hline Tot. bahan tercetak & 32 bahan \\
\hline \multicolumn{2}{|l|}{ Skrin \& bahan } \\
\hline Jumlah penggantian skrin & 7 kali \\
\hline Siklus pengeringan & 16 kali \\
\hline Pemasangan \& penyimpanan bahan & 4 kali \\
\hline
\end{tabular}

\section{Kesimpulan Dan Saran}

Teknik Micromotion Study dengan basis video sangat dianjurkan untuk pengamatan dalam analisis produktivitas sebuah aktivitas kerja yang berulang, teknik ini memungkinkan peneliti mengamati gerakan operator berulang kali dengan lebih teliti dikarenakan video dapat diputar secara slow motion, dipercepat, maupun dihentikan sementara, sehingga mengurangi potensi kehilangan data akibat tidak terdokumentasi saat pengamatan seperti dalam teknik visual motion study atau pengamatan langsung.

Desain Meja Panjang memiliki keunggulan pada kesederhanaan dan visibilitas sistem kerja terutama terhadap jumlah pekerjaan dalam pemasangan guide system, kemudahan penggantian skrin, dan kemudahan set-up skrin saat trouble-shooting, kekurangan yang dimiliki adalah mengenai guide system yang tidak memiliki akurasi yang baik, proses kalibrasi dan registrasi masih mengandalkan feeling operator dikarenakan desain guide system skrin/bahan tidak memiliki sistem pengunci, rendahnya efisiensi jarak transportasi, efisiensi waktu set-up, dan efisiensi penggunaan ruang, sehingga dapat menghambat proses naik cetak warna berikutnya bahkan proses produksi secara keseluruhan. Pengembangan desain baru atau redesain diarahkan kepada peningkatan produktivitas kerja berdasarkan kriteria pengembangan dari empat parameter yaitu efektivitas dan efisiensi ruang, guide system, kalibrasi, dan proses cetak. 
Tabel 5.1. Kelebihan dan kekurangan desain existing

\begin{tabular}{|c|c|}
\hline Kelebihan & Kekurangan \\
\hline 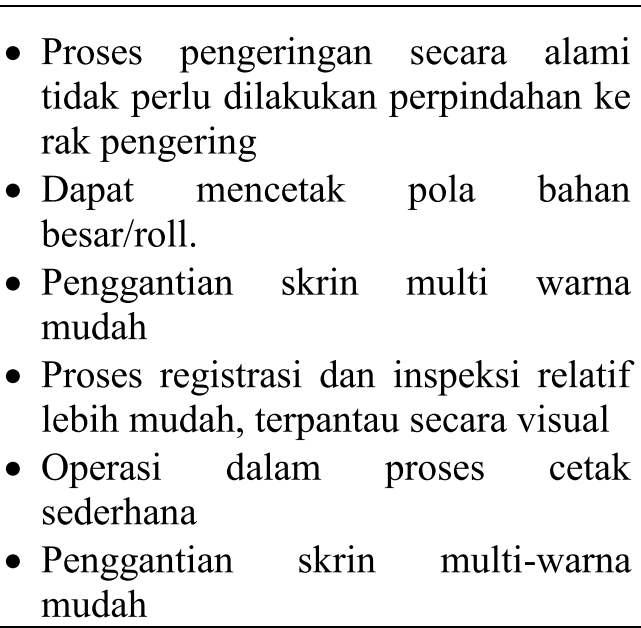 & $\begin{array}{l}\text { - Membutuhkan ruang yang lebih luas } \\
\text { untuk menghampar meja cetak. } \\
\text { - Kapasitas bahan yang dapat dipasang } \\
\text { sedikit/terbatas per-modul. } \\
\text { - Pemasangan bahan tidak dapat } \\
\text { dilakukan sekaligus } \\
\text { - Sistem registrasi skrin tidak memiliki } \\
\text { pengunci yang presisi. } \\
\text { - Jarak transportasi dalam proses cetak } \\
\text { maupun pengeringan tidak } \\
\text { efisien/sangat besar. }\end{array}$ \\
\hline
\end{tabular}

\section{Daftar Pustaka}

[1] Arimbawa. 2010. Redesain Peralatan Kerja Secara Ergonomis Meningkatkan Kinerja Pembuat Minyak Kelapa Tradisional di Kecamatan Dawan Klangkung. Bali: Udayana University Press.

[2] Arman H.N. 2006. Manajemen Industri. Yogyakarta: Andi Offset

[3] Badan Pusat Statistik Republik Indonesia. 2003. Ekonomi dan Perdagangan. Jakarta: BPSRI

[4] Bandi Sobandi. 2004. Model Pembelajaran Kewirausahaan Sablon dalam Menumbuhkan Minat Wirausaha Santri di Kecamatan Cisalak Kabupaten Subang. Bandung: Universitas Pendidikan Indonesia.

[5] Barnes R.M. 1980. Motion and Time Study, Design and Measurement of Work. Canada: John Wiley \& Son, Inc.

[6] Madyana. 1996. Analisis Perancangan Kerja dan Ergonomi. Yogyakarta: Penerbitan Universitas Atmajaya.

[7] Pigage \& Tucker. 1954. Motion and Time Study. Illinois: University of Illinois Bulletin, Vol.51.

[8] Wignjosoebroto, Sritomo. 2003. Ergonomi: Studi gerak dan waktu. Surabaya: Institut Teknologi Sepuluh Nopember. 